\section{Corporation Members}

Aerospace Corporation

AeroVironment Inc.

Air Traffic Services

Air Transport Association of America

Air Weather Service Technical Library

Alden Electronic and Impulse Recording Equipment Company, Inc.

Argonne National Laboratory

Audichron Company, Pastel Division

Bahamas Meteorological Department

Barbados Meteorological Service

Bechtel Power Corporation

Belfort Instrument Company

Beukers Laboratories, Inc.

Botswana Meteorological Services

Brock University Library

Calspan Corporation

Cardion Electronics

Caribbean Meteorological Institute

Centro Técnico Aerospacial. Divisao de Ciencias Atmosféricas

Climatronics Corporation

Colorado International Corporation

Colorado State University, Department of Atmospheric Science

Communications and Weather Research Foundation. Inc.

Control Data Corporation

Creighton University, Atmospheric Science Program

Deere and Company

E-Systems, Inc., Garland Division

Eastern Airlines, Inc.

Edinburgh University Library

Electric Speed Indicator Company. Inc.

Enterprise Electronics Corporation

Environmental Instruments, Inc.

Environmental Satellite Data, Inc.

ERT. Inc.

Exxon Research and Engineering Company

Factory Mutual Engineering Corporation

Fernbank Science Center

Florida State University, Department of Meteorology

Ford Aerospace and Communications Corporation/Western

Development Laboratories

Freeport International Weather Service

GEOMET, Incorporated

Global Weather Dynamics, Inc.

HANDAR

Harvard University

Illinois State Water Survey

Indian Institute of Tropical Meteorology

Information Systems and Networks Corporation

Irish Meteorological Service

Israel Embassy

ITT Aerospace/Optical Division

Jackson State University. Science Department

Kaijo Denki Co., Ltd.

Kaysam Corporation of America

Kean College of New Jersey

Lightning Location and Protection, Inc.

Massachusetts Institute of Technology, Department of Meteorology Met One. Inc.

Murray and Trettel Inc.. Consulting Meteorologists

National Agency of Environmental Protection. Roskilde, Denmark

National Meteorological Library of the United Kingdom
New Zealand Meteorological Service

North American Weather Consultants

NUS Corporation

Oceanroutes, Inc.

The Ohio State University, Atmospheric Sciences Program

Oregon State University, Department of Atmospheric Sciences

Pennsylvania State University, Department of Meteorology

Pennsylvania State University, Pattee Library

Philippine Weather Bureau

Purdue University

Qualimetrics, Inc., Weather Measure/Weathertronics Divisions

Queensland Electricity Generating Board (Australia)

RCA Astro-Electronics Division

Republic of Korea Air Force, 73rd Weather Group

Republic of Korea, Meteorological Research Institute

Research Triangle Institute

Royal Netherlands Meteorological Institute

Royal Observatory. Hong Kong

Rutgers University, Douglass-Cook Library

Safety and Security Systems Division/3M

Saint Louis University, Department of Earth and Atmospheric Sciences

San Jose State University. Department of Meteorology

South Dakota School of Mines and Technology

Southwest Research Institute, Applied Physics Division

Systems Applications. Inc.

Teledyne Geotech

Texas A\&M University, Department of Meteorology

Texas Department of Water Resources

Travelers Insurance Company

United States Naval Academy Library

Universität Freiburg. Meteorologisches Institut

Universität Innsbruck. Institut für Meteorologie and Geophysik

Universiti Kebangsaan Malaysia, Library

University Corporation for Atmospheric Research, National Center for Atmospheric Research

University of Arizona. Institute of Atmospheric Physics

University of California, Los Angeles. Department of Atmospheric Sciences

University of Chicago, Department of the Geophysical Sciences

University of Copenhagen, Institute for Theoretical Meteorology

University of Maryland, Department of Meteorology

University of Nevada. Desert Research Institute

University of North Carolina

University of Northern Colorado Library

University of Oklahoma, Department of Meteorology

University of Sheffield Library

University of Toronto Library

University of Washington. Department of Atmospheric Sciences

VIZ Manufacturing Company

Weather Consultants Incorporated

Weather Corporation of America

Weather Services Corporation

Weatherscan International

Western Australian Institute of Technology. School of Physics and Geosciences

Western Weather Consultants, Inc.

Westinghouse Electric Corporation

Woods Hole Oceanographic Institution

WSI Corporation

WTVT Television Weather Service

WWL Radio \& Television

Yale University, Department of Geology and Geophysics

R. M. Young Company 